\title{
Assessment of the dendrochronological potential of Licaria bahiana Kurz, an endemic laurel of lowland Atlantic forests in Brazil
}

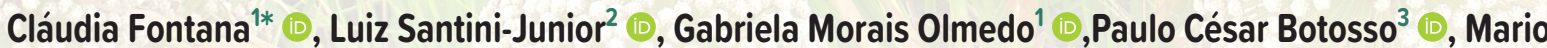 Tomazello-Filho ${ }^{2}$ (1) and Juliano Morales Oliveira' ${ }^{1}$ (1)}

Received: January 25, 2019

Accepted: April 10, 2019

\begin{abstract}
The Atlantic Forest of southeastern Brazil has been considered to have the highest number of tree species per hectare in the world. Assessing the influence of climate on tropical tree species is a priority in the face of ongoing climate change, and for which dendrochronological studies have been important. We address the dendrochronological potential of Licaria bahiana Kurz (Lauraceae), an endemic species of the Atlantic forests. We studied growth ring anatomy of $L$. bahiana and applied dendrochronological methods to investigate how short-term variation in climate affect its radial growth. Distinct growth rings were observed in all individuals and demarcated by darker tangential fiber zones in latewood. Trees showed high climatic sensitivity (0.48) and growth synchrony (intercorrelation $r=$ 0.69 ; $r$ bar $=0.38$ ). Radial growth was negatively influenced by high temperatures at the beginning of the current growing season $(r=-0.46)$ and by excessive rainfall at the end of the current growing season $(r=-0.29)$, which are periods that correspond to the phenological reproductive phases of the species. Climate anomalies during this period may alter the tradeoff between growth and reproduction, in favor of the latter.
\end{abstract}

Keywords: climate, dendroecology, Lauraceae, tree-rings, wood anatomy, Tabuleiro forests

\section{Introduction}

The analysis of annual growth rings in woody tissues, resulting from seasonal vascular cambium activity, provides detailed information about life histories of plants and their changing environment (Fritts 1976; Schweingruber 2007; Speer 2010). Growth-ring formation is widespread and very well documented in cold-zone floras (Schweingruber 2007), where dendrochronology has provided major insights into environmental and societal histories, such as climate change (Martinelli 2004) and civilization demises (Buntgen et al. 2011). In the tropics, dendrochronology has been hindered mainly by a long-lasting premise that the lack of winter cold results in continuous and/or erratic growth patterns in woody tissues, disregarding other possible triggering factors (Worbes 2002). Nevertheless, studies reporting annual growth rings in lianas (see Lima et al. 2010 and Brandes et al. 2015) and tree species from the equator to the subtropical belts have flourished since the 1980's, opening an avenue to the environmental history of tropical forests and savannas (Worbes 2002; Rozendaal \& Zuidema 2011; Brienen et al. 2016; Schöngart et al. 2017). The most elemental dendrochronological issue in the tropics is no longer whether woody plants form annual growth rings, but which of them do.

Obviously, answering that question is an enormous task. Since the tropics are estimated to have between 25,000 and 50,000 tree species (Hubbell 2013), the hundreds of species,

1 Universidade do Vale Rio dos Sinos, 93022-000, São Leopoldo, RS, Brazil

2 Escola Superior de Agricultura "Luiz de Queiroz", Universidade do São Paulo, 13418-900, Piracicaba, SP, Brazil

3 Embrapa Floresta, Empresa Brasileira de Pesquisa Agropecuária, 83411-000, Colombo, PR, Brazil

* Corresponding author: claudiafontanabio@gmail.com 
thus far know to form annual growth rings (Worbes 2002; Brienen et al. 2016; Schöngart et al. 2017), are likely to represent a tiny sample of its flora with dendrochronological potential. The megadiversity of tropical communities is linked to endemism and low population densities (Hubbell 2013), imposing a further logistic nuisance to the approach to its dendrochronology potential. The search for plants feasible to growth-ring analysis may be more prolific in plant communities under marked seasonal conditions and/or in lineages embracing species of recognizable potential (Roig 2000) if annual vascular cambium rhythm is environmentally driven and/or phylogenetically conserved (see Nath et al. 2016).

If plants are to be used in dendrochronology, beyond forming annual anatomical markers in the wood, these true annual growth-rings have to be distinguished from intraannual wood layers resulting from abnormal conditions during the growth season, especially when exact calendar age inference is mandatory, as in dendroclimatology (Fritts 1976). Thus, it is essential to assess the crossdating principle, i.e., the existence of a typical synchronous growth pattern within a population submitted to similar changing environmental (climatic) limiting factors (Douglass 1941; Fritts 1976). Again, dendrochronologists studying tropical communities have an enduring duty because crossdating has been evaluated for even fewer cases (see Fontana et al. 2018b).

Here, we aim to assess the dendrochronological potential of Licaria bahiana, a species of the family Lauraceae that is endemic to lowland Atlantic Neotropical forests (Quinet et al. 2015). For a population growing in a forest under seasonal rainfall regime, we asked the following questions: (i) Does L. bahiana form anatomically apparent growth layers in the wood? If so, (ii) is there a synchronous growth pattern among trees and what is the role of varying climatic conditions on that? We hypothesize that L. bahiana forms annual growth rings, with a synchronous width pattern due to the interannual variation in water supply, because: anatomically distinctive growth layers are widespread in Neotropical Lauraceae, and some cases have proven to be truly annual and sensitive to climate conditions (Reis-Ávila \& Oliveira 2017); seasonal rainfall regimes are a major determinant of growth-ring formation and inter-annual growth rhythms in tropical trees (Worbes 2002; Rozendaal \& Zuidema 2011; Brienen et al. 2016; Schöngart et al. 2017); annual and climate-sensitive growth rings were reported for species of Fabaceae in the same forest type we studied (Costa 2015; Costa et al. 2015; Fontana et al. 2018a).

\section{Materials and methods}

\section{Study area and tree species selected}

The study was carried out at the Reserva Natural Vale (RNV), an area of 23,000 ha covered by a well-preserved tropical rainforest called "Tabuleiros" Atlantic Forest (TAF). It is located in the State of Espírito Santo, in the southeastern region of Brazil (19 $9^{\circ} \mathrm{S}-19^{\circ} 14^{\prime} \mathrm{S}, 39^{\circ} 12^{\prime} \mathrm{W}$ $40^{\circ} \mathrm{W}$ ), between 30 and $80 \mathrm{~m}$ a.s.l., approximately $30 \mathrm{~km}$ from the coast of the Atlantic Ocean (Fig. 1).

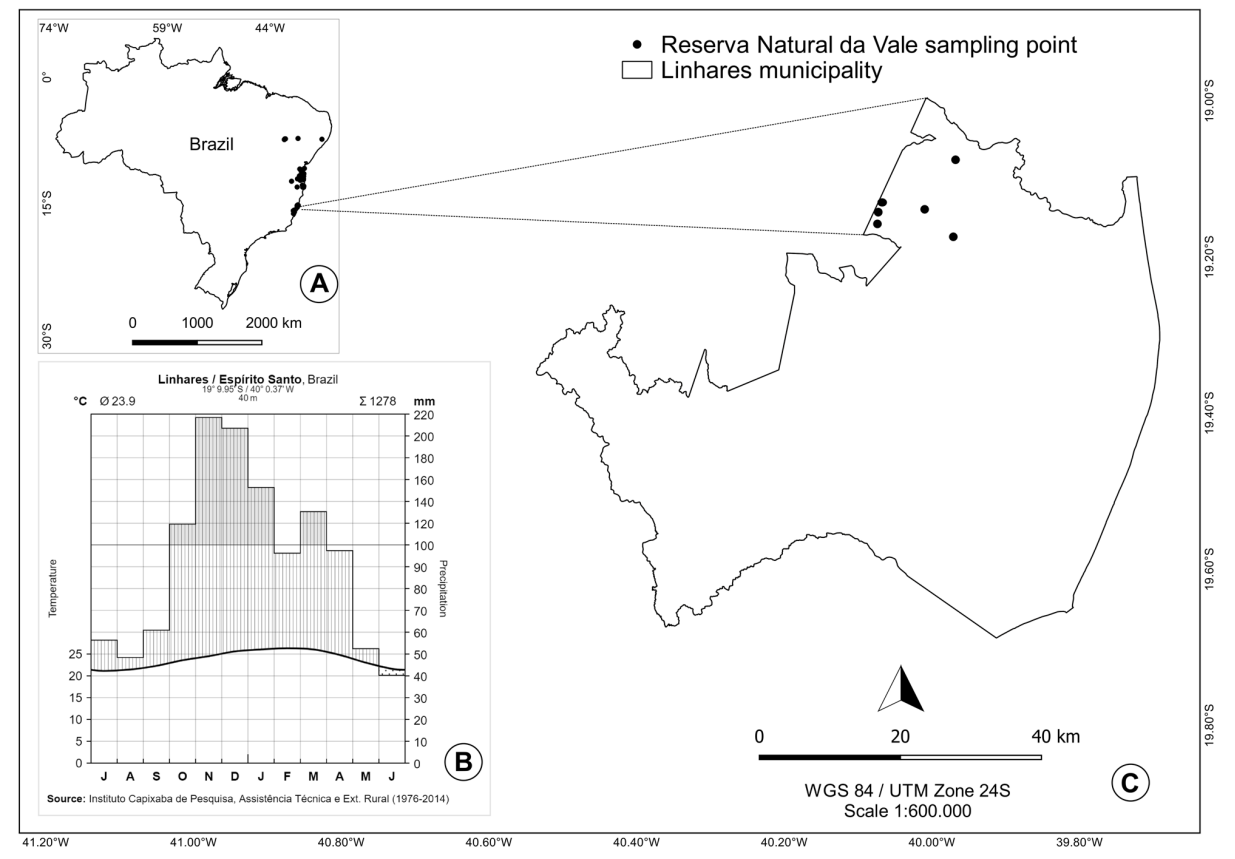

Figure 1. Study area in the State of Espírito Santo, southeastern Brazil. A. Location of the study area in Brazil. Dots represent the records of Licaria bahiana according to Species Link (http://www.splink.org.br/index?lang=pt). B. Climatic diagram of the study region; data provided by Instituto Capixaba de Pesquisa, Assistência Técnica e Extensão Rural (INCAPER). C. Location of the six sampled trees (dots) in the municipality of Linhares, Espírito Santo. 
According to the Koeppen classification (Alvares et al. 2014), the climate of the study region is type Aw, a markedly seasonal tropical climate with a dry winter season. Mean annual precipitation is $1,178 \mathrm{~mm}$, with monthly averages for the rainy season (spring and summer) of $130 \mathrm{~mm}$ to approximately $200 \mathrm{~mm}$ from October to April, when $72 \%$ of the precipitation occurs (Rolim et al. 2016). Rainfall during the dry season (winter) does not exceed $25 \%$ of the annual total, being below $60 \mathrm{~mm}$ from April to September (Víncens et al. 2003) (Fig. 1C). It is worth noticing the strong yearto-year variation in precipitation that can vary up to $50 \%$ (Garay et al. 2003). The mean temperature ranges between $19.9^{\circ} \mathrm{C}$ in July to $25.6^{\circ} \mathrm{C}$ in February through the year, and the overall annual mean is $23^{\circ} \mathrm{C}$ (Jesus 2001) (Fig. 1C). The relative humidity in RNV is of the $83 \%$ (Kindel et al. 1999). Evapotranspiration reaches on average $1,246 \mathrm{~mm}$ per year, with maximum values in the rainy season and frequently exceeding the dry season (Víncens et al. 2003).

Soils are predominantly yellow podzolic (yellow, tertiary argisol), dystrophic, with a drastic difference in grain size according to depth, presenting low fertility and low cationexchange capacity (Garay \& Silva 1995; Louzada et al. 1997). In small patches, there is the occurrence of "mussununga", with a characteristic Podzol-type soil, which is an azonal, sandy quaternary, fragile and unstructured soil, forming a layer with a certain thickness and with approximately $2 \mathrm{~m}$ from the groundwater level (Víncens et al. 2003).

TAF presents a floristic mixture of Amazonian and Atlantic elements (Rizzini 1963; Peixoto \& Gentry 1990; Veloso 1991; Siqueira 1994; Garay et al. 2003; Jesus \& Rolim 2005) and is considered to have the highest tree-species density per hectare in the world (Thomas et al. 2008). Due to the complexity of its flora, TAF is classified within the Lowland Dense Ombrophilous Forest and the Lowland Semideciduous Forest (Veloso 1991; IBGE 2012).

Licaria Aubl. (Lauraceae) is an endemic genus of the Neotropics with approximately $40-50$ species (Kurz 2000; Werff 2003; Baitello \& Esteves 2007). In Brazil, 21 species occur, three of which are endemic (Quinet et al. 2015). Among them is Licaria bahiana Kurz, subgenus Armeniaca (Richter 1985), with distribution in the lowland forests and "restingas" (sandbanks) of southeastern and northeastern Brazil (Leite 2010; Quinet et al. 2015), as well as in the "mussunungas" of the Reserva Natural Vale. These trees usually reach $22 \mathrm{~m}$ in height (Barbosa et al. 2012), with larger individuals attaining $41 \mathrm{~m}$ in height and diameters up to $83 \mathrm{~cm}$ (Sambuichi 2006). As for phenology, it flowers in January, with immature fruits in February and April and mature fruits in October (Barbosa et al. 2012). For foliar phenology, local observations and exsiccatae deposited in the herbarium of the RNV indicate that the tree is evergreen. It is monoecious (Quinet 2005) and classified as late secondary (Evaristo et al. 2011). In phytosociological studies, L. bahiana presents low density, with one to two individuals per hectare (Sambuichi 2006; Leite 2010).
Thus, it can be classified as a rare species according to the theory of singletons (species represented by only a single individual) and doubletons (species represented by up to two individuals) proposed by Preston (1962).

\section{Sampling and analyzing the growth ring markers}

To verify whether L. bahiana forms anatomically distinct tree rings in the wood, we took wood cores of 5 $\mathrm{mm}$ diameter, collected at breast height $(\sim 1.30 \mathrm{~m})$ with an increment borer (Haglöf, Långsele, Sweden), from six adult individuals with average height of $12 \mathrm{~m}(8-21 \mathrm{~m})$ and diameter at breast height $(\mathrm{DBH})$ of $15 \mathrm{~cm}(9-25 \mathrm{~cm})$. All individuals were geo-referenced (Fig. 1A).

For macroscopic description, cores were sanded with micro abrasive paper according to Stokes \& Smiley (1996) and photographed using a camera attached to a stereomicroscope (Canon DS126311, Tokyo, Japan). We analyzed the transverse surfaces of six wood cores (one per tree). We looked for features that determine ring boundaries, as well as anomalies within the ring that differ from the typical growth ring boundaries (possible false rings).

For microscopic description, we produced histological slides by boiling the wood cores in water and glycerin for approximately 8 hours. We prepared safranin-stained histological slides for the transversal anatomical plane, according to standard techniques in wood anatomy (Johansen 1940; Sass 1958). Sections, 8-15 $\mu$ m thick, were cut on a rotary microtome (Micron HM 340E, Walldorf, Germany) and mounted on microscope slides. Digital images were captured with a camera (AVT Marlin F-145C2, Stadtroda, Germany) attached to a microscope (Olympus BX50, Tokyo, Japan). Cell dimensions were measured using the Image Pro Plus 4.5 software (Media Cybernetics 2001). The main descriptions of macro- and microscopic features of transversal plane of the wood follow the IAWA Committee (1989) and Coradin \& Muñiz (1991).

\section{Dendrochronology}

\section{Wood sampling and preparation}

For tree-ring analysis, we used the same trees described above. For each tree, we collected two to four increment cores (radii) at breast height (DBH), using a 5-mm diameter increment borer (Haglöf, Långsele, Sweden). Wood cores were air-dried and then glued to wooden holders. After drying, cross-sections were polished with sandpaper (from 80 to 1200 grit) until the anatomical structure of the ring boundaries were clearly distinguishable.

The wood cross-sections were visually crossdated within each tree under a stereomicroscope (Zeiss MZ8) and the growth-layer boundaries were identified and marked. We also considered wood anomalies, such as deformed cells, vessel distribution and patterns of fiber wall thickness, as 
possible time markers (Wils et al. 2009; 2011). Wood crosssections were then scanned with a high resolution at 2400 DPIs (Epson Perfection V750 PRO) with a reference scale. The tree-ring widths were measured using the Image Pro Plus software (Media Cybernetics 2001).

\section{Crossdating and chronology building procedures}

For assessment, measurement control and crossdating among radii, we used the COFECHA software (Holmes 1983; 1986), in which we crossdated time series within trees using segment lengths of 20 years with 10 -year overlaps. After the crossdating procedures were satisfactorily performed within-trees, we used the Arstan software to enhance a common growth signal, stabilize variance and integrate the tree series in a site chronology (Cook 1985; Cook \& Holmes 1996). To enhance a common (climatic) signal among the trees, ontogenetic and disturbance trends were filtered from each raw ring-width series by dividing each ring-width value by its predicted value obtained from a cubic smoothing spline model ( $50 \%$ of variance maintained in 21 year segments) adjusted for each series. The resulting standardized ring-width series were then combined in a mean site chronology through a robust bi-weighted mean function.

The growth synchronism among series was evaluated by the Intercorrelation among standardized series, computed within ( $r$ wit) and among (rbet) trees, by the Mean Correlation among standardized series (rbar) and by the Expressed Population Signal (EPS); the temporal variation of the mean site chronology was described by its Standard Deviation (SD) and Mean Sensitivity Index (MSI) (Speer 2010). MSI among series, $r$ wit and $r$ bet were computed using COFECHA (Holmes 1983) and MSI of site chronology and the other parameters using ARSTAN (Cook \& Holmes 1996).

\section{Dendroclimatic signals}

To explore radial growth responses to climatic conditions, we compared the mean site chronology to precipitation and temperature data, provided by the Instituto Capixaba de Pesquisa, Assistência Técnica e Extensão Rural (INCAPER), from a meteorological station $10 \mathrm{~km}$ away from the study site. The monthly meteorological series covers the period from 1976 to 2014, with sparse gaps (12 months for precipitation and 16 months for temperature), that were filled with the respective monthly average. We used Correlation Function Analysis (Blasing et al. 1984) to test for dendroclimatic signals in L. bahiana, by comparing the site chronology to monthly total precipitation and temperature ( mean $=$ Tmean ; minimum $=$ Tmin , and maximum $=$ Tmax ). We tested the radial growth responses to climatic conditions through the previous and current growth year by correlating the STD chronology to climatic series from October (spring) of the previous growth year to April (autumn) of the current growth year. The statistical significance of the correlation coefficients was addressed on a $95 \%$ confidence interval obtained by bootstrap resampling (Biondi \& Waikul 2004). Correlation Function Analyses were performed in the package bootRes of R (Zang \& Biondi 2013). Pearson's correlations were calculated for the period 1976-2013 to verify the agreement between climatic variables and STD chronology.

\section{Results and discussion}

\section{Wood anatomy}

Macroscopic description: Growth ring boundaries distinct, visible to the naked eye, delimited by variations in fiber-wall thickness resulting in a distinct darker tangential fiber zone in latewood, sometimes associated with axial marginal parenchyma forming a thin line (rare). Axial parenchyma scanty paratracheal, visible under lens (10x), vasicentric and, sometimes, linear aliform, forming small confluence stretches among the vessels. Rays visible under lens of $10 \times$, fine and few, irregularly spaced. Vessels visible to the naked eye, predominantly solitary and multiples up to four, wood diffuse-porous, small to medium-sized (Fig. 2A-C).

Microscopic description: Vessels solitary (predominant) or multiples up to 7; vessel clusters up to 4 were rare; wood diffuse-porous, without typical arrangement, of circular to angular section; frequency of $5-20$ vessels $/ \mathrm{mm}^{2}$; tangential diameter of 30-132 $\mu \mathrm{m}$; sometimes obstructed by tyloses or partially filled with gum deposits. Axial parenchyma scanty, paratracheal vasicentric (but typically not completely surrounding the vessels) to lozange-aliform (but without forming distinct bands); axial parenchyma in marginal narrow lines. Ray frequency was low, with 2-5 rays $\mathrm{mm}^{-}$ ${ }^{1}$ width 1 to 3 cells. Intercellular canals absent. Crystals absent. Tyloses with thin walls sometimes present (Fig. 2D).

The presence of growth rings in trees and lianas in Brazilian forests has been described for many species. In a meta-analysis of the wood anatomy involving 491 species occurring in Brazil, Alves \& Angyalossy-Alfonso (2000) identified that $48 \%$ of them form an anatomical growth marker, while Mainieri et al. (1983) observed it in $38 \%$ of the 300 species analyzed by them. Reis-Ávila \& Oliveira (2017) reviewed the literature on the anatomy of the growth rings of 113 species of neotropical Lauraceae. They report that $90 \%$ had clearly distinct ring boundaries, most of them distinct by variation in fiber density and only a few to marginal parenchyma. Although all these authors do not mention how many of these species form annual rings, Brienen et al. (2016) confirm annual growth rings for 230 tropical tree species embracing continents and climatic zones. Studies of cambial activity and xylogenesis in Brazilian trees also confirm the formation of annual rings for many species 
(Callado et al. 2001; 2014; Lisi et al. 2008; Oliveira et al. 2009; Brandes et al. 2015; Vasconcellos et al. 2016).

According to Alves \& Angyalossy-Alfonso (2000), Licaria camara (only species of Licaria investigated in the study) presents distinct growth rings, diagonal vessels, solitary and multiple. Hernandez (2002) evaluated the anatomy of seven Licaria species. The authors observed both an absence of growth rings and rings defined by lumen reduction and/ or fiber wall thickening, diffuse-porous wood, solitary and multiple vessels, without specific arrangements. The online platform InsideWood (http: //insidewood.lib.ncsu.edu/ search, cf. Wheeler 2011) documents the wood anatomy of about 18 Licaria species. Of these, there are descriptive data for 10 of them, reporting indistinct or absent growth ring boundaries. Record \& Hess (1942) evaluated 11 species of Licaria and observed that when present, the growth ring boundaries are distinct by slight differences in density and sometimes by a line of marginal parenchyma. In our analyzes, $L$. bahiana also presents marginal parenchyma but not at all ring boundaries. Dünisch et al. (2002) studied the wood formation in Carapa guianensis for four years; only in one of them was a parenchyma band formed.

In this context, it is observed that growth rings occur in a few Licaria species, and are not very distinct in some of them. Thus, L. bahiana is among the few species of this genus that form distinct growth rings, allowing dendrochronological studies. These studies can bring important contributions to the understanding of genus ecology.

\section{Dendrochronology}

We cross-dated 16 series for six L. bahiana trees. The main chronology descriptors are presented in Table 1. Many of the dendrochronological parameters evaluated indicate that the chronology was cross-dated successfully. It also reached the critical correlation pointed out by COFECHA ( $99 \%$ confidence level $=0.5155$ ), indicating consistency in the common growth variation among the site trees. The age structure comprises trees of estimated mean age of 38 years (26-50 years).
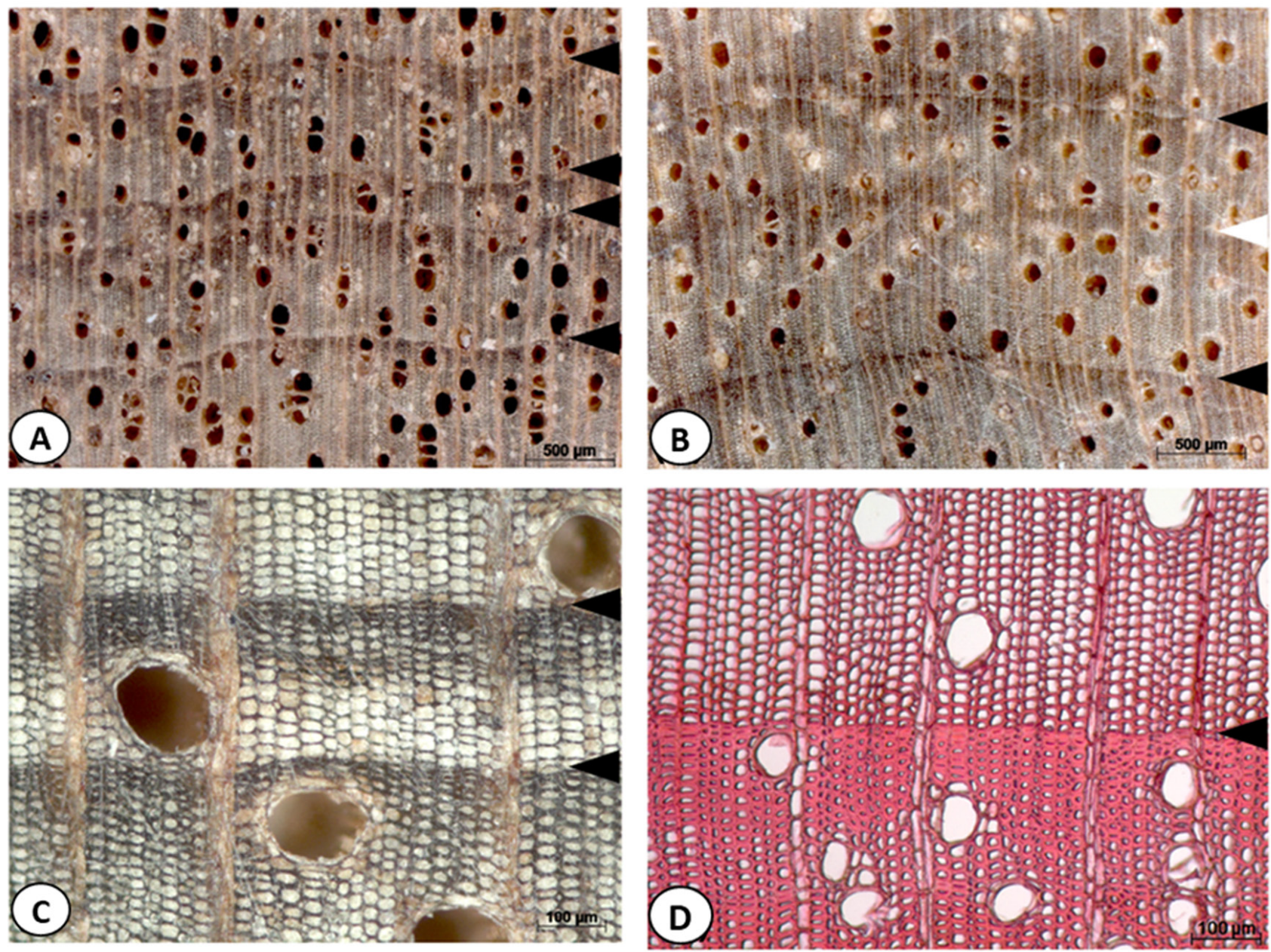

Figure 2. Wood transversal section of Licaria bahiana. Macroscopy: A. General aspect of the wood and distinct growth ring boundaries (black arrow); B. Typical annual growth rings (black arrow) and false rings (intra-annual density fluctuation; white arrow); and $\mathbf{C}$. Aspect of a narrow growth ring. D. Microscopic detail of an abrupt transition between two growth-rings, from latewood thick-walled cells in the former ring to earlywood thin-walled cells in the latter. 
Table 1. Statistical parameters of Licaria bahiana ring-width chronology, from "Tabuleiros" Atlantic Forest.

\begin{tabular}{|c|c|}
\hline Parameter & Values \\
\hline Crossdated period & 1965 - 2014 (50 years) \\
\hline $\begin{array}{l}\text { Mean length of series } \\
\text { (year) }\end{array}$ & $\begin{array}{c}38 \text { years }(\operatorname{Min}=26 ; \operatorname{Max}=50 \\
\qquad S D= \pm 12)\end{array}$ \\
\hline $\begin{array}{l}\text { Average annual growth } \\
\text { (mm/year) }\end{array}$ & $\begin{array}{c}2.15(\operatorname{Min}=0.27 ; \operatorname{Max}=6.79 ; \\
S D= \pm 1.21)\end{array}$ \\
\hline Individual series & \\
\hline $\begin{array}{l}\text { Intercorrelation within tree-series } \\
\text { ( } r \text { wit) }\end{array}$ & $\begin{array}{c}0.69(\operatorname{Min}=0.62 ; \operatorname{Max}=0.76 ; \\
S D= \pm 0.07)\end{array}$ \\
\hline $\begin{array}{l}\text { Intercorrelation between tree-series } \\
\text { ( } r \text { bet) }\end{array}$ & $\begin{array}{c}0.55(\mathrm{Min}=0.42 ; \operatorname{Max}=0.66 ; \\
\mathrm{SD}= \pm 0.10)\end{array}$ \\
\hline $\begin{array}{l}\text { Mean Correlation among series } \\
\text { (rbar) }\end{array}$ & $\begin{array}{c}0.38(\operatorname{Min}=0.27 ; \operatorname{Max}=0.47 ; \\
S D= \pm 0.07)\end{array}$ \\
\hline Mean Expressed Population Signal & 0.74 \\
\hline $\begin{array}{l}\text { Mean Sensitivity Index } \\
\text { (MSI) }\end{array}$ & $\begin{array}{c}0.48(\operatorname{Min}=0.35 ; \operatorname{Max}=0.69 ; \\
S D= \pm 0.16)\end{array}$ \\
\hline Site chronology & \\
\hline $\begin{array}{l}\text { Standard deviation } \\
\text { (SD) }\end{array}$ & 0.067 \\
\hline Mean Sensitivity Index & 0.37 \\
\hline First-order Autocorrelation & -0.092 \\
\hline
\end{tabular}

Licaria bahiana showed to be very sensitive to environmental variations, with a great alternation between wide and narrow rings (MSI = 0.48; Fig. 2A). According to Speer (2010), MSI above 0.4 indicates high sensitivity and frequency of micro or missing rings next to very wide rings, causing increased difficulty in dating. In this sense, wood anatomy microscopy of L. bahiana played an important role to better understand the growth ring anatomical patterns and recognizing them macroscopically.

Considering the STD chronology, the mean correlation between all pairs of trees was $r$ bar $=0.38$ and varied throughout the chronology (Fig. 3A). In studies investigating the relationships between tree growth and climate in the Brazilian Atlantic Forest, this parameter varied from 0.20 up to 0.69 (Dünisch 2005; Oliveira et al. 2010; VenegasGonzález et al. 2016; Fontana et al. 2018a; Granato-Souza et al. 2018a; 2019). Thus, by comparison, the L. bahiana chronology has a median correlation considering the forest pattern. It should be noticed that, due to the low density of $L$. bahiana trees, we could sample only six trees. Despite this, it was possible to evidence the sensitivity and growth synchronism among them.

Nevertheless, the EPS in the entire period was below the threshold of 0.85 suggested by Wigley et al. (1984) (Fig. 3A). According to the authors, the EPS tells how well the mean of a finite sample represents the average of a hypothetical population. The value is influenced by the number of replications. Thus, the value increases rapidly from one to 10 trees and gradually stabilizes from this point on (Cook \& Kairiukstis 1990). There are recent discussions above the overvaluation of this parameter (Mérian et al. 2013; Buras 2017). In studies developed in the Atlantic Forest, EPS is the least used parameter to contribute to the validation of the chronology (Fontana et al. 2018b). In the case of $L$. bahiana, which presented satisfactory values for the other parameters, the increase in the number of trees in the chronology could only reinforce this evidence of synchronism.

For analyses of climate relations, we only used a representative part of the STD chronology in order to maintain a period of common growth for most trees and to fit it in the period with available local climatic data (19762013).

Licaria bahiana showed radial growth negatively influenced by high temperatures at the beginning of the current growing season (November Tmean $=-0.46$; $T$ min $=-0.41 ; \operatorname{Tmax}=-0.48)$. Excessive rainfall at the end of the current growing season also presented a negative effect on its performance (February $r=-0.29$ ). Although this correlation is weak, it is significant (Fig. 4).

Temperature is the limiting factor for tree growth in temperate and cool zones, whereas in the tropics it is nearly constant (Worbes 2002). In fact, most studies in the tropics have reported correlations between growth and rainfall (see a review in Rozendaal \& Zuidema 2011). In the Neotropical forest, with increasing latitude and altitude (subtropics), photoperiod and temperature become important in annual growth rhythms (Schöngart et al. 2017). On the other hand, temperature correlations have not even been tested in many climatic studies in tropical regions. This is because it is assumed that the low fluctuation of the annual temperature is unable to trigger physiological responses in tropical trees. In spite of that, currently, more studies have tested the relationship between growth and temperature, demonstrating the influence of this climatic variable on the radial growth of the tropical trees (e.g., López \& Villalba 2011; Vlam et al. 2014; Fétéké et al. 2016; Locosselli et al. 2016a; b; Vasconcellos et al. 2016; Pereira et al. 2018; Rahman et al. 2018).

The tropical species L. bahiana showed to be sensitive to the high temperatures of November, thus corresponding to the beginning of the growth season. This pattern was also reported for Podocarpus lambertii in northeastern Brazil, where, associated with site conditions, November temperature was the main limiting factor for growth in that population (Locosselli et al. 2016a). High temperatures increase the Vapor Pressure Deficit (VPD) (Kramer \& Kozlowski 1972; Will et al. 2013; Marchin et al. 2016; Shamshiri et al. 2018), increasing the demand of the plant for water (Will et al. 2013; Lihavainen et al. 2016; Shamshiri et al. 2018), causing the closing of the stomata and blocking 


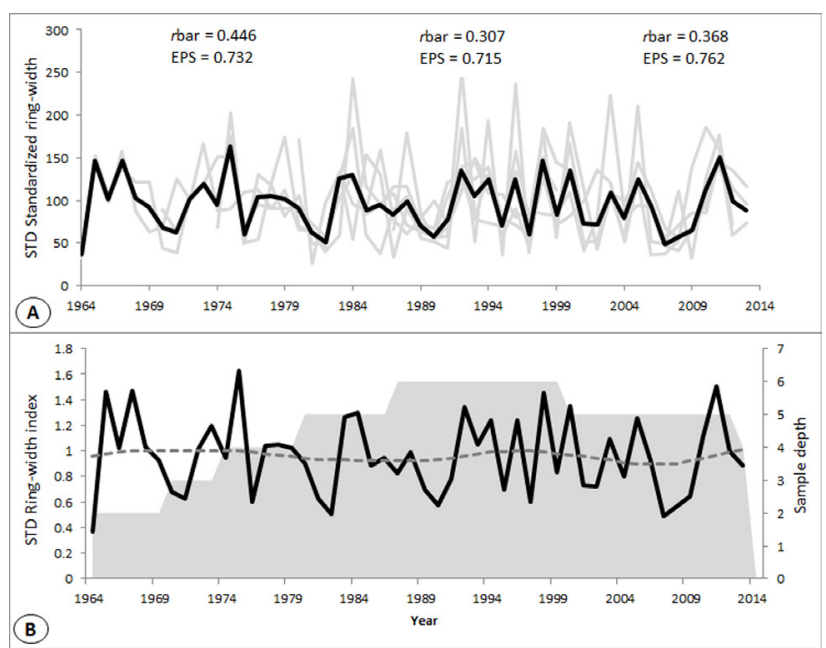

Figure 3. A. Individual ring-width series of Licaria bahiana (gray lines) and their mean curve (black line) from "Tabuleiros" Atlantic Forest in Brazil; B. Ring-width Index chronology (black line) of Licaria bahiana and 21-years smoothing curve (dotted line). The area in light gray shows sample depth over the analysis period.

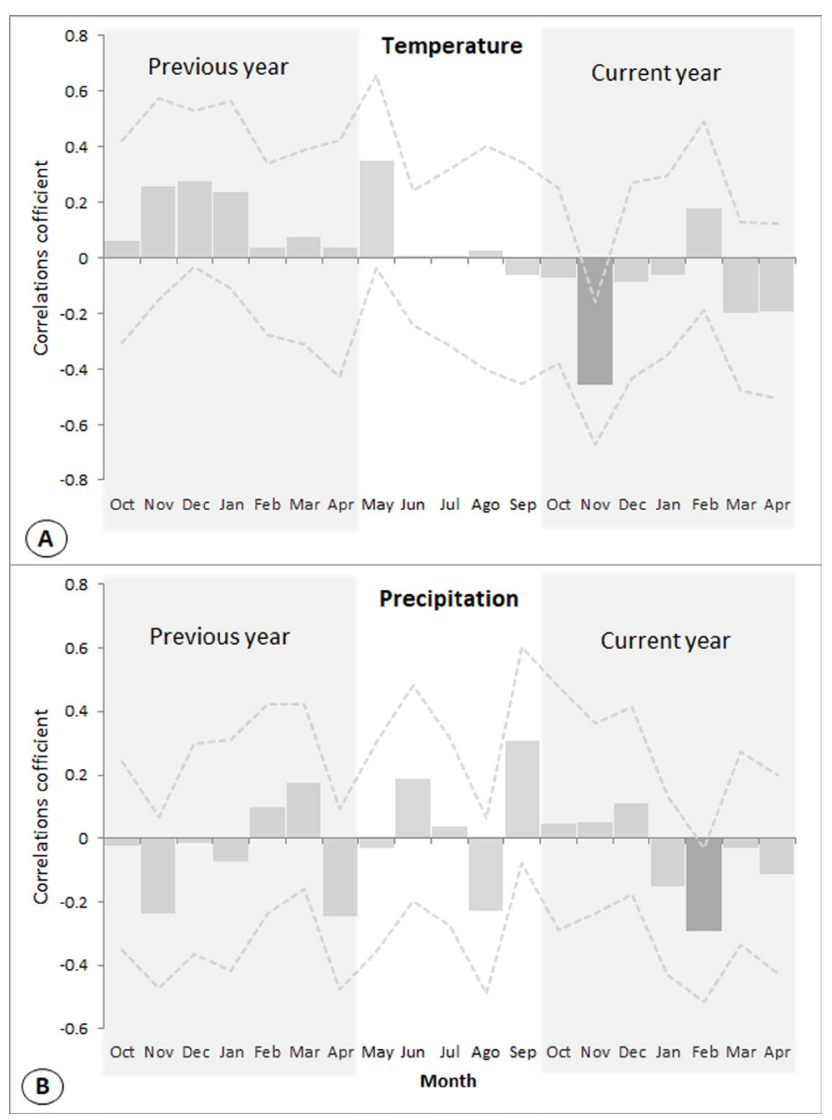

Figure 4. Correlations between ring-width index and climatic variables (1976-2013). orrelation among ring-width index, $\mathbf{A}$. mean temperature and B. total precipitation. Columns in dark gray indicate month with significance levels at $\mathrm{p}<0.05$. Dotted lines delimit the $95 \%$ confidence interval. Light-gray areas show the estimated growth season period. the entry of $\mathrm{CO} 2$ through them, which in turn reduces the photosynthesis rate (Saliendra et al. 1995; Streck 2003; lio et al. 2004; Will et al. 2013). Voelker et al. 2014 studying Quercus macrocarpa across continental gradients in precipitation, VPD and irradiance, found a negative correlation between the chronology and the wettest region. They conclude that the magnitude and sign of correlations between tree-ring chronologies corresponded to regional shifts in VPD or the ratio of precipitation to evapotranspiration. Rahman et al. (2018) also reported negative significance in a tropical moist forest tree in Bangladesh related to radial growth and VPD, particularly in the later growing season. The authors explained that there is higher evapotranspiration outside the main monsoon season, when the environment becomes extremely dry, with low relative humidity (RH), higher VPD, and low soil moisture. An increase in temperature in this phase could increase water stress leading to low growth (Rahman et al. 2018).

An important ecological feature of L. bahiana is the ability to occupy "restinga" and "mussununga" habitats. In the study area, L. bahiana occurs in the latter, as well as in ombrophilous forests. An edaphic factor that differentiates "mussunungas" from "restingas" is the presence of an impermeable layer of laterite in the former that causes seasonal flooding in this habitat and gives it high humidity during the rainy season (Meira-Neto et al. 2005). In turn, water saturation reduces soil available oxygen, which can affect the height, leaf, cambial and reproductive growths of trees (Kozlowski 1986). This condition may explain the negative correlation between precipitation and growth that we found for L. bahiana. Dendrochronological studies developed in the Amazonian floodplains also showed a negative correlation between ring width and the amount of precipitation and flood pulse during the vegetation period (Schongart et al. 2004). In Brazil, with the exception of the ecosystems investigated by Schongart et al. (2004), other studies in tropical climate showed strong influence of precipitation in the radial growth (Callado \& Guimarães 2010; Brandes et al. 2011; Latorraca et al. 2015; Locosselli et al. 2016b; Souza et al. 2016; Granato-Souza et al. 2019; Vasconcellos et al. 2019), whereas negative correlations are more often in subtropical climate (Oliveira et al. 2010; Andreacci \& Botosso 2014; Perone et al. 2016; Kanieski 2017; Granato-Souza et al. 2018a; b). As in L. bahiana, a study carried out with Chukrasia tabularis A. Juss. in Bangladeshi moist tropical forests showed that precipitation negatively influenced tree growth in the later growing season (Rahman et al. 2018). According to the authors, this period corresponds to the end of the monsoon season and the soils are moisture saturated. An increase in precipitation in this monsoon phase may further increase soil moisture leading to anoxia in the root zone.

In addition, the increase of precipitation in February may lead to an increase in $\mathrm{RH}$, which is one of the factors that influence VPD. High RH is related to low VPD (Zhang et 
al. 2017). Low VPD promotes stomatal opening, facilitating the entry of carbon dioxide $\left(\mathrm{CO}_{2}\right)$ (Saliendra et al. 1995; Lihavainen et al. 2016). This could promote growth by the CO2 gain being applied to photosynthesis (Streck 2003). However, low VPD decreases the evaporative demand and may reduce the acquisition and translocation of minerals, especially nitrogen, via xylem sap flux rates (Lihavainen et al. 2016). Studying Betula pendula, Lihavainen et al. (2016) showed that low VPD affects carbon and nutrient homeostasis and modifies nitrogen allocation of plants. These issues may have contributed to the low performance of L. bahina in relation to high precipitation during the late growing seasson.

Studies have also shown that in Amazonian floodplain ecosystems, the peak of flowering and fruiting occurs during the flood pulse (Schöngart et al. 2002). Licaria bahiana flowers in January and the fruits begin to develop in February (Barbosa et al. 2012), the rainy season period in the region. Therefore, these are months of high energy demand by the plant. In the climatic diagram (Fig. 1C) February is usually the driest month of the growing season. Anomalies in climate during this period can alter the tradeoff between growth and reproduction, favoring the latter. Studies with tropical species have shown that correlations of radial growth with phenophases are variable depending on the species (Fétéké et al. 2016). Lara \& Marcati (2016) studied the cambial activity and phenology of the evergreen species Cordiera concolor. The authors demonstrated that the flower buds and flowering coincides with the end of the growing season in February for some specimens, while other specimens remain with mature leaves or new green leaves in the same period. Thus, it seems that the variability found in phenology at the species level (Fétéké et al. 2016) is repeated at the specimen level. In this context, it would be necessary to carry out cambial activity and phenology studies to better understand the relationship between these parameters and growth for L. bahiana. Especially because L. bahiana is a monoecious species (Quinet 2005).

For Southeastern Brazil, the report by the Brazilian Panel on Climate Change (PBMC 2014) points to a 2.5 to $3{ }^{\circ} \mathrm{C}$ increase in temperature by the end of the century, with an increase in rainfall from $25 \%$ to $30 \%$, extreme events of rain, drought and temperature, more frequent and intense. Despite being stenotopic (restricted geographic distribution), L. bahiana is a euryecious species, that is, capable of populating different habitats. Thus, reducing cambial activity may be the mechanism by which this species copes with extreme events in the environment. Given the climatic scenario projected for the region, it is possible that L. bahiana will reduce its annual growth rate. However, it is important to keep in mind that understanding responses of forests to global changes through tree ring analysis is not an easy task and can be plagued by biases, such as recruitment patterns, demographic processes, successional groups and others (Brienen et al. 2017).
This was the first dendrochronological study for Licaria bahiana. This species is endemic to the Brazilian flora, has limited distribution and, as most tropical species, occurs with low density. In this study, we demonstrated that that the growth rings are well marked and synchronous in this population and high temperatures and rainfall reduced its radial growth. Since L. bahiana is a representative of rare species, which in turn contributes to the high diversity of tropical forests, it is important to understand their responses to a rapidly changing climate. In this context, the scenarios of increasing extreme events in precipitation and temperature may indicate risks to the conservation of L. bahiana in the long term. It is important that other rare species be investigated to understand their responses to these ongoing climate changes.

\section{Acknowledgements}

We thank Embrapa Florestas for the financial support, to Wagner Farias Silva and the field assistants Edilson da Silva and Marcos de Castro.. o Geovane Siqueira for the botanical identification;to INCAPER for providing the climate base and the colleagues of the UNISINOS, especially Gabriela Reis-Ávila. We thank the Editors and the anonymous reviewers for contributions. This work was supported by the Empresa Brasileira de Pesquisa Agropecuária, Confederação Nacional da Agricultura (CNA); and Reserva Natural Vale for support with hosting.

\section{References}

Alvares CA, Stape JL, Sentelhas PC, et al.2014. Koppen's climate classification map for Brazil. Meteorologische Zeitschrift 22: 711728.

Alves ES, Angyalossy-Alfonso V. 2000. Ecological trends in the wood anatomy of some Brazilian species. 1. Growth rings and vessels. IAWA Journal 21: 3-30.

Andreacci F, Botosso P. 2014. Sinais climáticos em anéis de crescimento de Cedrela fissilis em diferentes tipologias de florestas ombrófilas do sul do Brasil. Floresta 44: 323-332.

Baitello JB, Esteves R. 2007. Licaria Aubl. In: Wanderley MGL, Shepherd GJ, Giulietti AM, Melhem TSA. (eds.) Flora fanerogâmica do estado de São Paulo. São Paulo, FAPESP. p. 165-167.

Barbosa TDM, Baitello JB, Moraes PLR de. 2012. A família Lauraceae Juss. no município de Santa Teresa, Espírito Santo. Boletim do Museu de Biologia Mello Leitão 30: 5-178.

Biondi F, Waikul K. 2004. DENDROCLIM2002: A C++ program for statistical calibration of climate signals in tree-ring chronologies. Computers and Geosciences30: 303-311.

Blasing TJ, Solomon AM, Duvick DN. 1984. Response function revisited. Tree-Ring Bulletin 44: 1-15.

Brandes AFN, Lisi CS, Silva LDSAB, et al. 2015. Seasonal cambial activity and wood formation in trees and lianas of Leguminosae growing in the Atlantic Forest: a comparative study. Botany 93: 211-220.

Brandes AFN, Lisi CS, Barros CF. 2011. Dendrochronology of lianas of the Leguminosae family from the Atlantic Forest, Brazil. Trees - Structure and Function 25: 133-144.

Brienen RJW, Gloor M, Ziv G. 2017. Tree demography dominates longterm growth trends inferred from tree rings. Global Change Biology 23: 474-484. 


\section{Cláudia Fontana, Luiz Santini-Junior, Gabriela Morais Olmedo, Paulo César Botosso, Mario Tomazello-Filho and Juliano Morales Oliveira}

Brienen RJW, Schöngart J, Zuidema A. 2016. Tree rings in the tropics: Insights into the ecology and climate sensitivity of tropical trees. In: Goldstein G, Santiago LS. (eds.) Tropical Tree Physiology: adaptations and responses in a changing environment. Cham, Springer. p. 439-461.

Buntgen U, Tegel W, Nicolussi K, et al. 2011. 2500 years of European climate variability and human susceptibility. Science 331: 578-582.

Buras A. 2017. A comment on the expressed population signal. Dendrochronologia 44: 130-132.

Callado CH, Vasconcellos TJ, Costa MS, et al. 2014. Studies on cambial activity: Advances and challenges in the knowledge of growth dynamics of Brazilian woody species. Anais da Academia Brasileira de Ciências 86: 277-283.

Callado CH, Guimarães C. 2010. Estudo dos anéis de crescimento de Schizolobium parahyba (Leguminosae: Caesalpinioideae) após episódio de mortalidade em Ilha Grande, Rio de Janeiro. Revista Brasileira de Botânica 33: 85-91.

Callado CH, Silva Neto SJS, Scarano FR, Costa CG. 2001. Periodicity of growth rings in some flood-prone trees of the Atlantic Rain Forest in Rio de Janeiro, Brazil. Trees - Structure and Function 15: 492-497.

Cook ER. 1985. A time series analyses approach to tree ring standardization. $\mathrm{PhD}$ Thesis, University of Arizona, Tucson.

Cook ER, Holmes RL. 1996. Guide for computer program ARSTAN. In: Grissino-Mayer HD, Holmes RL, Fritts HC. (eds.) The international tree-ring data bank program library version 2.0 user's manual. Tuscson, Laboratory of Tree-Ring Research, University of Arizona. p. 75-87.

Cook ER, Kairiukstis L. 1990. Methods of dendrochronology - Applications in the environmental sciences. Laxenburg, Klumer Academic Publisher.

Coradin VTR, Muñiz GIB. 1991. Normas e procedimentos em estudos de anatomia de madeira: I. Angiospermae II. Gimnospermae. IBAMA, DIRPED, LPF, Série técnica 15: 17.

Costa MS. 2015. Dendrocronologia e caracterização do crescimento radial de espécies da família Leguminosae em uma Floresta Estacional Semidecidual das Terras Baixas: Mata Atlântica. PhD Thesis, Universidade Estadual do Rio de Janeiro, Rio de Janeiro.

Costa MS, Ferreira KEB, Botosso PC, Callado CH. 2015. Growth analysis of five Leguminosae native tree species from a seasonal semidecidual lowland forest in Brazil. Dendrochronologia 36: 23-32.

Douglass AE. 1941. Crossdating in dendrochronology. Journal of Forestry 39: 825-831.

Dünisch O. 2005. Influence of the El-niño southern oscillation on cambial growth of Cedrela fissilis Vell. in tropical and subtropical Brazil. Journal of Applied Botany and Food Quality 79: 5-11.

Dünisch O, Bauch J, Gasparotto L. 2002. Formation of increment zones and intraannual growth dynamics in the xylem of Swietenia macrophylla, Carapa guianensis, and Cedrela odorata (Meliaceae). IAWA Journal 23: 101-119.

Evaristo VT, Braga JMA, Nascimento MT. 2011. Atlantic forest regeneration in abandoned plantations of Eucalypt (Corymbia citriodora (Hook.) K.D. Hill and L.A.S. Johnson) in Rio de Janeiro, Brazil. Interciencia. Org 36: 431-436.

Fétéké F, Fayolle A, Dainou K, et al. 2016. Variations saisonnières de la croissance diamétrique et des phénologies foliaire et reproductive de trois espèces ligneuses commerciales d' Afrique centrale. Bois et Forêts des Tropiques 4: 3-21.

Fontana C, Pérez-de-Lis G, Nabais C, et al. 2018a. Climatic signal in growthrings of Copaifera lucens: An endemic species of a Brazilian Atlantic forest hotspot, southeastern Brazil. Dendrochronologia 50: 23-32.

Fontana C, Reis-Avila G, Botosso PC, Oliveira JM. 2018b. Dendrochronology and climate in the Brazilian Atlantic Forest: Which species, where and how. Neotropical Biology and Conservation 13: 321-333.

Fritts HC. 1976. Tree rings and climate change. 1st. edn. New York, Academic Press Inc Ltd.

Garay I, Kindel A, Louzada MAP, Santos D. 2003. A Floresta Atlântica de Tabuleiros: diversidade funcional da cobertura arbórea. Petrópolis, Vozes.

Garay I, Silva BAO. 1995. Húmus florestais: síntese e diagnósticos das interrelações vegetação/solo. Oecologia Brasiliensis 1: 19-46.

Granato-Souza D, Adenesky-Filho E, Barbosa ACMC, Esemann-Quadros K. 2018a. Dendrochronological analyses and climatic signals of Alchornea triplinervia in subtropical forest of southern Brazil. Austral Ecology 43: 385-396

Granato-Souza D, Adenesky-Filho E, Esemann-Quadros K. 2018b. Dendrochronology and climatic signals in the wood of Nectandra oppositifolia from a dense rain forest in southern Brazil. Journal of Forestry Research 30: 545-553.

Granato-Souza D, David S, Ana WS, et al. 2019. Tree rings and rainfall in the equatorial Amazon. Climate Dynamics Published 52: 1857-1869.

Hernandez WJL. 2002. Anatomía del xilema caulinar de 14 especies de Lauraceae. Revista Forestal Venezolana 46: 15-25.

Holmes RL. 1983. Computer-assisted quality control in tree-ring dating and measurement. Tree-Ring Bulletins 43: 69-78.

Holmes RL. 1986. Quality control of crossdating and measuring: a user's manual for program COFECHA. In: Holmes RL, Adams RK, Fritts HC. (eds.) Tree-ring chronologies of western North America: California, eastern Oregon and northern Great Basin with procedures used in the chronology development work including user's manuals for computer programs COFECHA and ARSTAN. Tucson, Laboratory of Tree-Ring Research, University of Arizona. p. 41-49.

Hubbell SP. 2013. Tropical rain forest conservation and the twin challenges of diversity and rarity. Ecology and Evolution 3: 3263-3274.

IAWA Committee. 1989. Iawa listo of microscopic features for harwood identification. IAWA Bulletins 10: 219-332.

IBGE. 2012. Manual técnico da vegetação brasileira. 2nd. edn. Série manuais técnicos de geociências. Rio de Janeiro, Coordenação de Recursos Naturais e Estudos Ambientais.

Iio A, Fukasawa H, Nose Y, Kakubari Y. 2004. Stomatal closure induced by high vapor pressure deficit limited midday photosynthesis at the canopy top of Fagus crenata Blume on Naeba mountain in Japan. Trees 18: 510-517.

Jesus RM. 2001. Manejo florestal: impactos da exploração na estrutura da floresta e sua sustentabilidade econômica. PhD Thesis, Universidade de Campinas, Campinas.

Jesus RMD, Rolim SG. 2005. Fitossociologia da Mata Atlântica de Tabuleiro. Boletim Técnico. Sociedade de Investigações Florestais 17: 1-154.

Johansen DA. 1940. Plant Microtechnique. 3rd. edn. New York/ London, McGraw-Hill Book Company, Inc.

Kanieski MR. 2017. Dendroecologia de Sebastiania commersoniana (Baill.) L . B . Sm . \& Downs e Hovenia dulcis Thunb . em uma área degradada na floresta ombrófila mista aluvial, sul do Brasil. Ciência Florestal 27: 1201-1215.

Kindel A, Barbosa PMS, Garay I. 1999. Efeito do extrativismo seletivo de espécies arbóreas da floresta atlântica de tabuleiros na matéria orgânica e outros atributos do solo. Revista Brasileira de Ciências do Solo 23: 465-474.

Kozlowski TT. 1986. Soil aeration and growth of forest trees. Scandinavian Journal of Forest Research 1: 113-123.

Kramer PJ, Kozlowski TT. 1972. Fisiologia das árvores. Lisboa, Calouste Gulbenkian.

Kurz H. 2000. A revision of the genus Licaria (Lauraceae). Mitteilungen aus dem Institut für allgemeine Botanik in Hamburg 2000: 89-221.

Lara NOT, Marcati CR. 2016. Cambial dormancy lasts 9 months in a tropical evergreen species. Trees 30: 1331-1339.

Latorraca JVF, Souza MTS, Baptista LDSA, Ramos LMA. 2015. Dendrocronologia de árvores de Schizolobium parahyba (Vell.) S. F. Blake de ocorrência na REBIO de Tinguá-RJ. Revista Árvore 39: 385-394.

Leite VR. 2010. Análise estrutural e da vulnerabilidade ambiental de um fragmento florestal de restinga ao sul do estado do Espírito Santo. MSc Thesis, Universidade Federal do Espírito Santo, Vitória.

Lihavainen J, Ahonen V, Keski-saari S, et al. 2016. Low vapour pressure deficit affects nitrogen nutrition and foliar metabolites in silver birch. Journal of Experimental Botany 67: 4353-4365.

Lima AC, Pace MR, Angyalossy V. 2010. Seasonality and growth rings in lianas of Bignoniaceae Seasonality and growth rings in lianas of Bignoniaceae. Trees 24: 1045-1060

Lisi CS, Tomazello-Fo M, Botosso PC, et al. 2008. Tree-ring formation, radial increment periodicity, and phenology of tree species from a Seasonal Semi-deciduous Forest in Southeast Brazil. IAWA Journal 29: 189-207. 


\section{Assessment of the dendrochronological potential of Licaria bahiana Kurz, an endemic laurel of lowland Atlantic forests in Brazil}

Locosselli GM, Cardim RH, Ceccantini G. 2016a. Rock outcrops reduce temperature-induced stress for tropical conifer by decoupling regional climate in the semiarid environment. International Journal of Biometeorology 60: 639-649.

Locosselli GM, Schöngart J, Ceccantini G. 2016b. Climate/growth relations and teleconnections for a Hymenaea courbaril (Leguminosae) population inhabiting the dry forest on karst. Trees - Structure and Function 30: 1127-1136.

López L, Villalba R. 2011. Climate Influences on the Radial Growth of Centrolobium microchaete, a valuable timber species from the tropical dry forests in Bolivia. Biotropica 43: 41-49.

Louzada MAP, Curvello A, Barbosa JHC, Garay I. 1997. O aporte de matéria orgânica ao solo: quantificação, fenologia e suas relações com a composição específica em área de Floresta Atlântica de Tabuleiros. Leandra 12: 27-32.

Mainieri C, Chimelo JP, Alfonso VA. 1983. Manual de identificação das principais madeiras comerciais brasileiras. São Paulo, Promocet.

Marchin R, Broadhead AA, Hoffmann WA. 2016. Stomatal acclimation to vapor pressure deficit doubles transpiration of small tree seedlings with warming transpiration of small tree seedlings with warming. Plant, Cell \& Environment 39: 2221-34.

Martinelli N. 2004. Climate from dendrochronology: latest developments and results. Global Planet Change 40: 129-139.

Media Cybernetics. 2001. Image-Pro Plus. Rockville, Media Cybernetics Inc.

Meira-Neto JAA, Souza AL, Lana JM, Valente GE. 2005. Composição florística, espectro biológico e fitofisionomia da vegetação de muçununga nos municípios de Caravelas e Mucuri, Bahia. Revista Árvore 29: 139-150.

Mérian P, Pierrat JC, Lebourgeois F. 2013. Effect of sampling effort on the regional chronology statistics and climate-growth relationships estimation. Dendrochronologia 31: 58-67.

Nath CD, Munoz F, Pélissier R, et al. 2016. Growth rings in tropical trees: role of functional traits, environment, and phylogeny. Trees 30: 2153-2175.

Oliveira JM, Roig FA, Pillar VD. 2010. Climatic signals in tree-rings of Araucaria angustifolia in the southern Brazilian highlands. Austral Ecology 35: 134-147.

Oliveira JM, Santarosa E, Pillar VD, Roig FA. 2009. Seasonal cambium activity in the subtropical rain forest tree Araucaria angustifolia. Trees - Structure and Function 23: 107-115.

PBMC. 2014. Base científica das mudanças climáticas. Contribuição do Grupo de Trabalho 1 do painel brasileiro de mudanças climáticas ao primeiro relatório da avaliação nacional sobre mudanças climáticas. Rio de Janeiro, COPE, Universidade Federal do Rio de Janeiro.

Peixoto AL, Gentry A. 1990. Diversidade e composição florística da mata de Tabuleiro na Reserva Florestal de Linhares, Espírito Santo, Brasil. Revista Brasileira de Botânica 13: 19-25.

Pereira MG, Carvalho DC, Vicente J, et al. 2018. Dendrochronology and growth of Copaifera langsdorffii wood in the vegetative dynamics of the Pirapitinga Ecological Station, State of Minas Gerais, Brazil. Floresta 48: 49-58.

Perone A, Lombardi F, Marchetti M, et al. 2016. Evidence of solar activity and El Nino signals in tree rings of Araucaria araucana and A. angustifolia in South America. Global Planet Change 145: 1-10.

Preston FW. 1962. The canonical distribution of commonnes and rarity: Part I. Ecology 43: 185-215.

Quinet A. 2005. Sinopse taxonômica da família Lauraceae no Estado do Rio de Janeiro, Brasil. Acta Botanica Brasilica 19: 563-572.

Quinet A, Baitello J, Moraes PL, et al. 2015 Licaria. In: Flora do Brasil 2020 em construção. Jardim Botânico do Rio Janeiro. http://floradobrasil. jbrj.gov.br. 20 Apr. 2018.

Rahman M, Islam M, Wernicke J. 2018. Changes in sensitivity of tree-ring widths to climate in a tropical moist forest tree in Bangladesh. Forests 9: 761 . doi: 10.3390/f9120761

Record SJ, Hess RW. 1942. American timbers of the family Lauraceae. Trop Woods 69: 7-33.

Reis-Ávila G, Oliveira JM. 2017. Lauraceae: A promising family for the advance of neotropical dendrochronology. Dendrochronologia 44: 103-116.
Richter HG. 1985. Wood and bark anatomy of Lauraceae. 11. Licaria aublet. IAWA Bull 6: 187-199.

Rizzini CT. 1963. Nota prévia sobre a divisão fitogeográfica do Brasil. Revista Brasileira de Geografia 1: 1-64.

Roig FA. 2000. Dendrocronología en los bosques del Neotrópico: revisión y prospección futura. In: Roig FA. (ed.) Dendrocronología en América Latina. Mendoza, EDIUNC. p. 307-355.

Rolim SG, Ivanauska NM, Engel VL. 2016. As florestas de tabuleiro do norte do Espírito Santo São ombrófilas ou estacionais? In: Rolim SG, Menezes LFT, Srbek-Araujo AC. (eds.) Floresta Atlântica de Tabuleiro: diversidade e endemismo na Reserva Natural Vale. 1st. edn. Belo Horizonte, Rona Editora. p. 47-60.

Rozendaal DMA, Zuidema PA. 2011. Dendroecology in the tropics: A review. Trees - Structure and Function 25: 3-16.

Saliendra NZ, Sperry JS, Comstock JP. 1995. Influence of leaf water status on stomatal response to humidity, hydraulic conductance, and soil drought in Betula occidentalis. Planta 196: 357-366.

Sambuichi RHR. 2006. Estrutura e dinâmica do componente arbóreo em área de cabruca na região cacaueira do sul da Bahia, Brasil. Acta Botanica Brasilica 20: 943-954.

Sass JE. 1958. Elements of Botanical Microtechnique. 3rd. edn. New York/ London, McGraw-Hill Book Company, Inc.

Schöngart J, Bräuning A, Barbosa ACMC, et al. 2017. Dendroecological studies in the Neotropics: History, status and future challenges. In: Amoroso MM, Daniels LD, Baker PJ, Camarero JJ. (eds.) Dendroecology: tree-ring analyses applied to ecological studies. Cham, Springer. p. 35-73.

Schöngart J, Piedade MTF, Ludwigshausen S, et al. 2002. Phenology and stem-growth periodicity of tree species in Amazonian floodplain forests. Journal of Tropical Ecology 18: 581-597.

Schöngart J, Wolfgang JJ, Piedade MTF, Ayres JM, Huttermann A, Worbes M. 2004. Teleconnection between tree growth in the Amazonian floodplains and the El Ninõ - Southern Oscillation effect. Global Change Biology 10: 683-692.

Schweingruber FH. 2007. Wood structure and environment. Berlin/ Heidelberg/ Birmensdorf, Springer-Verlag.

Shamshiri RR, Jones JW, Thorp KR, et al. 2018. Review of optimum temperature, humidity, and vapour pressure deficit for microclimate evaluation and control in greenhouse cultivation of tomato: a review. International Agrophysics 32: 287-302.

Siqueira MF. 1994. Análise florística e ordenação de espécies arbóreas da mata atlântica através de dados binários. MSc Thesis, Universidade de Campinas, Campinas.

Souza BT, Estrada GCD, Soares MLG, Callado CH. 2016. Occurrence of annual growth rings in Rhizophora mangle in a region with low climate seasonality. Anais da Academia Brasileira de Ciências 88: 517-525.

Speer JH. 2010. Fundamentals of tree-ring research. Tucson, University of Arizona Press.

Stokes MA, Smiley TL. 1996. An introduction to tree-ring dating. Tucson, University of Arizona Press.

Streck NA. 2003. Stomatal response to water vapor pressure deficit: An unsolved issue - a review. Revista Brasileira de Agrociência 9: 317-322.

Thomas WW, Carvalho AMV, Amorim AM, et al. 2008. Diversity of woody plants in the Atlantic Coastal Forest of Southern Bahia, Brazil. In: Thomas W, Britton E. (eds.) The Atlantic Coastal Forests of Northeastern Brazil. New York, The New York Botanical Gardesn Press. p. 21-66.

Vasconcellos TJ, Costa MS, Barros CF, et al. 2016. Growth dynamics of Centrolobium robustum (Vell.) Mart. ex Benth. (LeguminosaePapilionoideae) in the Atlantic Forest. Brazilian Journal of Botany 39: 925-934.

Vasconcellos TJ, Tomazello-filho M, Callado CH. 2019. Dendrochronology and dendroclimatology of Ceiba speciosa (A. St.-Hil.) Ravenna (Malvaceae) exposed to urban pollution in Rio de Janeiro city, Brazil. Dendrochronologia 53: 104-113.

Veloso HP. 1991. Classificação da vegetação brasileira adaptada a um sistema universal. 1st. edn. Rio de Janeiro, IBGE.

Venegas-González A, Chagas MP, Anholetto Júnior CR, et al. 2016. Sensitivity of tree ring growth to local and large-scale climate variability 


\section{Cláudia Fontana, Luiz Santini-Junior, Gabriela Morais Olmedo, Paulo César Botosso, Mario Tomazello-Filho and Juliano Morales Oliveira}

in a region of Southeastern Brazil. Theoretical and Applied Climatology 123: 233-245.

Víncens RS, Agarez FV, Garay I. 2003. A região da REBIO Sooretama e da Reserva de Linhares e seu entorno: das características físico-geográficas ao uso da terra. In: Garay I, Rizzini CM. (eds.) A Floresta Atlântica de Tabuleiros: diversidade functional da cobertura arbórea. 1st. edn. Petrópolis, Vozes. p. 7-15.

Vlam M, Baker PJ, Bunyavejchewin S, Zuidema PA. 2014. Temperature and rainfall strongly drive temporal growth variation in Asian tropical forest trees. Oecologia 174: 1449-1461.

Voelker SL, Meinzer FC, Lachenbruch B, et al. 2014. Drivers of radial growth and carbon isotope discrimination of bur oak (Quercus macrocarpa Michx.) across continental gradients in precipitation, vapour pressure deficit and irradiance. Plant, Cell \& Environment 37: 766-779.

Werff H. 2003. New taxa of Lauraceae from South America. Niovon 13: 337-357.

Wheeler EA. 2011. InsideWood - A web resource for hardwood anatomy. IAWA Journal 32: 199-211.

Wigley TML, Briffa KR, Jones PD. 1984. On the average value of correlated time series, with applications in dendroclimatology and hydrometeorology. Journal of Climate and Applied Meteorology 23: 201-213.
Will RE, Wilson SM, Zou CB, Hennessey TC. 2013. Increased vapor pressure deficit due to higher temperature leads to greater transpiration and faster mortality during drought for tree seedlings common to the forest - grassland ecotone. New Phytologist 200: 366-374.

Wils THG, Robertson I, Eshetu Z, Sass-Klaassen UGW, Koprowski M. 2009. Periodicity of growth rings in Juniperus procera from Ethiopia inferred from crossdating and radiocarbon dating. Dendrochronologia 27: 45-58.

Wils THG, Robertson I, Eshetu Z, Touchan R, Sass-Klaassen U, Koprowski M. 2011. Crossdating Juniperus procera from North Gondar, Ethiopia. Trees - Structure and Function 25: 71-82.

Worbes M. 2002. One hundred years of tree-ring research in the tropics - a brief history and an outlook to future challenges. Dendrochronologia 20: 217-231.

Zang C, Biondi F. 2013. Dendroclimatic calibration in R: The bootRes package for response and correlation function analysis. Dendrochronologia 31: 68-74.

Zhang D, Du Q, Zhang Z, et al. 2017. Vapour pressure deficit control in relation to water transport and water productivity in greenhouse tomato production during summer. Scientific Reports 7: 43461. doi: 10.1038/srep43461 